\title{
South Sudan and the Emerging Security Implications for East Africa
}

\author{
Aldo Ajou Deng Akuey \\ Postgraduate Student (PhD), Philosophy of Political Science, Mku, Kenya
}

Copyright $(2018$ by authors, all rights reserved. Authors agree that this article remains permanently open access under the terms of the Creative Commons Attribution License 4.0 International License

\begin{abstract}
South Sudan achieved political independence in 2011 , before plunging into a series of civil wars that have culminated with the signing of the Inter-Governmental Authority for Development, IGAD, driven peace agreement. The Sudan People's Liberation Movement, SPLM, Government has not created conducive environment for political stability in South Sudan. Thus, the political and economic crisis has seen the intervention of neighboring countries in internal affairs of South Sudan to pursue their national interests or within the context of regional bodies such as IGAD to achieve the same. From the outset, the independence of South Sudan was necessitated by the USA led war against global terrorism that is more pronounced at the Horn of Africa and in the context of Sudan's civil war. The natural resources in South Sudan has attracted state and non-state actors with global and regional actors directly or indirectly getting involved in reconfiguring the security matrix with diverse outcomes, some of them with unintended outcome. Wildlife trafficking, gold mining, logging, ivory poaching and illegal charcoal production and commercial bush meat poaching, has created war economics and resource conflicts within the region and beyond. Political crisis in South Sudan, especially the most recent one that triggered civil war in 2013, and persisted to date, has received very little scholarly attention especially its regional security implications. This paper seeks to analyse the security ramifications of the ongoing war for East Africa. The paper will examine the emerging security threats and their regional ramifications. In particular, multiple security ramifications such as armed groups, humanitarian crisis, natural resources and refugees' crisis will be examined in detail to draw conclusions on the scope and depth of the emerging security threats in East Africa.
\end{abstract}

Keywords Security Threat, Independence, Peace Agreement, Foreign Interests, Global Terrorism

\section{Introduction}

The events of September 9/11/2001 in the United States of America, redefined security in Africa and securitized state, environment, economy, society, politics and the military itself. The turning point in Africa was the formation of AFRICOM in 2007 culminating with the entrenchment of the doctrine of political realism. Furthermore, security was refined and expanded to include non-state aspects of security. This was taking place at a time Africa was emerging from political instability associated with failed political and economic reforms that entrenched choice less democracies in various countries across the continent. Neoliberal globalization had taken heavy toll on the post-colonial state in Africa creating weak, failed or failing states. This article seeks to do the following. Firstly with reference to South Sudan, we seek to analyze the emerging security threats and how such threats can impact on the stability of the East African sub region. The second section of the paper suggests how emerging security threats could be addressed. The paper relies on the works of Barry Buzan and Copenhagen school of security analyzing emerging security threats and how they could be addressed.

Barry Buzan [1993; 4-8; 1998: 9-16] considers military, political, economic and environmental aspects as central towards understanding of security globally. To this could be added energy security, natural resources, energy, land, oil and minerals as important variables of analyzing security. Therefore, it could be argued that insecurity in Africa has internal and external attributes both which are intertwined or interrelated. Security threats emerging in South Sudan are therefore similar to other threats Africa is experiencing but there are specific or particular threats that confront South Sudan unique to the state in particular. International terrorism, organized crime, human and drug trafficking, money laundering, ethnic, land, religious and inter communal conflicts prevalent are a manifestation of these factors. Although the causes of conflicts in Africa are many and vary, economic difficulties, unresolved social and national question, elections related violence and rivalries among or between ethnic groups are considered primary.

The state in Africa since the 1980s has failed to play its 
traditional role due to the burden placed on it by the first generation structural adjustment programs. Whereas there has been some recovery, sustained social development and strong state in Africa is yet to take root. Indeed, the status quo emphasized by the western countries through stability or through western military presence in Africa directly or through proxies. There has been an increased terrorist attack, massacres, ethnic cleansing and even declaration of state of emergencies for the incumbents to stay or extent their rule in Africa. Cumulatively, these factors can be attributed to proliferation of weak or failed states in Africa. Internally, threats beneath and beyond have been central in highlighting some of the threats notable over the last few years.

\section{Environmental Crimes 8 Migration Patterns in Africa}

\section{An at-a-glance view of the sub-Saharan nations experiencing a growing flux of migrants, many of whom are fleeing countries racked by one or more types of environmental crimes.}

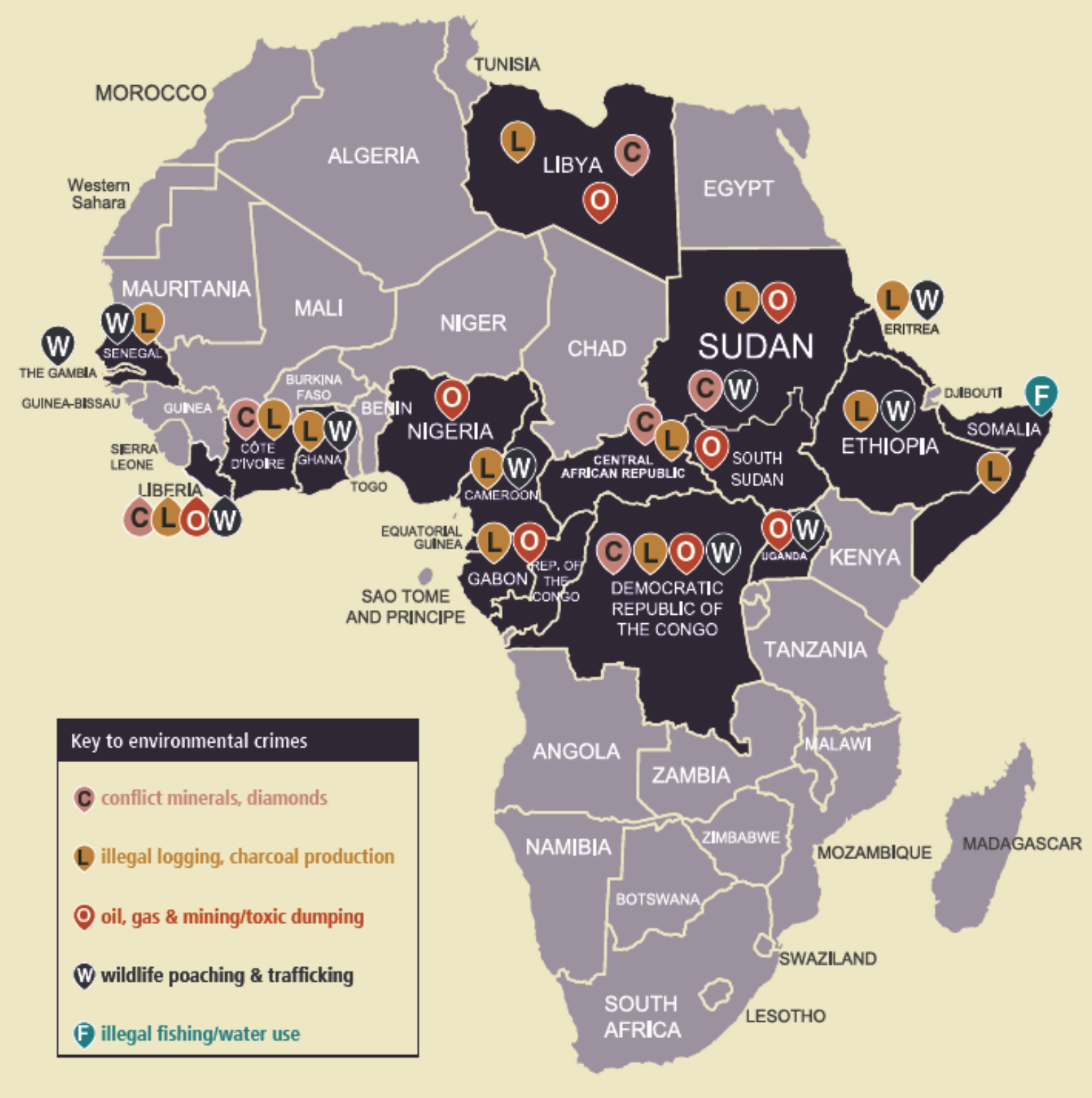


South Sudan became independent in 2011 after years of armed struggle and civil war. Like elsewhere in post-colonial Africa, there was great sense of optimism and hope for better lives. On the contrary, the country went back to civil war a year after the independence triggering new waves of civil wars and threats before fresh wars erupted. Since December 2013, South Sudan has not experienced political stability rather moved from one crisis to another [Mamdani, 2016:6-9; De waal, 2014:7-13]. Thus, South Sudan has all the hallmarks of a failed state. The emerging security threats that South Sudan faces is a reflection of its geography, cultural diversity and political history as one unified and tied with that of the Republic of Sudan.

The state in South Sudan is weak and underdeveloped to the extent that it cannot undertake its Westphalia functions and roles. In 2011, the state inherited lack of governing structures and institutions together with political and social glue that could hold the country together. The legacy of the war and ethnic manipulation by the political elites saw inter communal conflicts across the country. Khartoum regime used divide and rule tactics, setting one ethnic group against the other or pastoral communities against others with the result that communities were polarized and politically marginalized especially those who did not support the armed liberation struggle by the Sudan People's Liberation Movement[De Waal, 2014:7-12; Bereketeab, 2014:89-92]. Put differently, the task of state and nation building was to start from the scratch without any corresponding structures and initiatives. From history therefore, the most serious security threats are internal driven by weak or failed states inability to ensure security to all the citizens and their properties [Magnus, 2017:41-43]. Due to the nature and history of South Sudan, there have been so many militias operating independently of the state and occasionally challenging and contesting state power through the disgruntled politicians and former generals in the military. South Sudan government has so many ungoverned spaces and militias to the extent that the government has no legitimate security agencies that guarantee security hence proliferation of small and light weapons together with ungoverned spaces within.

The military in South Sudan permeates all aspects of people's lives, as it's the key political actor. The Sudan People's Liberation Movement, SPLM, government did not make a transition from a liberation movement and government to a civilian regime with proper and functional state organs of governance. The military dominates politics with civilian structures overlooked or nonexistence [De waal, 2014; Mamdani, 2016:11-16]. In other words, the state lacks legitimate civilian structures of governance. State institutions such as the judiciary, bureaucracy and security agencies rarely function or at best adhoc and dysfunctional. Nonexistent institutions of governance has created avenue for informal economy and rent seeking in South Sudan. To be sure, rampant or ubiquitous corruption is a result of weak or failed state.

Within the SPLM, power struggle and failure to meet people's expectations has caused elite rifts that have led to civil wars such as the sustained wars that started in December 2013. The power struggle that have assumed ethnic dimensions and caused serious insecurity within have securitized other sectors such as natural resources, environment, energy and transnational crime as criminal organized gangs engage in trade across the national borders with established groups with political motivations over war economy[Magnus, 2017; Muriithi, 2014:32-40; Obala, 2012:11-15]. Ungoverned spaces between South Sudan and its neighbors especially the border regions along Democratic Republic of Congo, Central African Republic, Sudan, Ethiopia and Uganda, have internationalized the conflict and instability as a result of resource based pull factors. The war economy associated with poaching of animals such as elephants, tiang, giraffe, chimpanzee, antelopes have attracted poaching and commercial trafficking of wildlife by the military, other armed groups and civilians as well. Wildlife and natural resources have fuelled corruption and armed conflicts across South Sudan [Theisen and others, 2017: 41-43]. Other illegal activities that pause insecurity in South Sudan are gold mining, illegal logging and charcoal production. International individuals in collaboration carry out these activities with locals, including members of security organs and other armed groups operating without South Sudan. Non-timber products such as wild coffee, gum acacia and shea also contribute to war along the savannah and equatorial forests (Collier, 2015:18-21). The Mbororo for example have moved freely along the DRC, Central Africa, Sudan and South Sudan borders, engaging in both legal and illegal trade from proceeds of poaching and natural resources exploitation.

Economic interests among the front line states such as Kenya, Uganda, Ethiopia, and Sudan have internationalized the conflict as evident by the post 2013 political conflicts and interventions both militarily and diplomatically by these actors through Inter Governmental Authority for Development, IGAD, or individual states to end the war or support respective agencies. Kenya for example, has invested in banking, construction, insurance, aviation, and hospitality, wholesale, transportation, and information and communication technology and retail trade. As from 2012 Kenya's exports to South Sudan accounted for $10.2 \%$ of total exports to Common Markets for Eastern and Southern Africa (COMESA) (KBS, Economic survey, 2013) and forth-largest export destination in COMESA. Furthermore, Kenya and Uganda have established and committed to undertake major infrastructure projects together such as the LAPSSET to link and open up the northern development corridor with railway, road, airports and resort cities in Isiolo, Lamu and Turkana counties (Muriithi, 2014:12-21). The war and political instability in South Sudan has the real effect of 
delaying or reversing these huge infrastructure projects in both countries with adverse consequences on regional and continental developmental blue print.

Uganda's interests in South Sudan are both economic and security and its intervention in Juba to protect national installations and Juba Airport, explains the significance of the two variables and security implications post 2013 South Sudan crises and war thereafter. Uganda regards South Sudan as a critical trading partner in goods and services [Obala, 2012; Irin, 2014:1]. The role of Lord's Resistance Army operating along Central African Republic, DRC and Sudan, has a destabilizing effect, as the lawless South Sudan would provide them with safe grounds to regroup. Most importantly are the large numbers of refugees potentially viewed as source of insecurity? President Museveni of Uganda offered strong military and diplomatic support to SPLM/SPLA after the end of the cold war and established personal friendship with the SPLM leader, DR. John Garang de Mabior, to protect Uganda's national interest and South Sudan's security threats to its national interests. A very complex security and threats emerge from geopolitical and security matrixes across East African front line states. The fact that they do not often read from the same scripts regionalizes and internationalizes the conflict in South Sudan making it difficult to resolve [Knopf, 2016:9-11].

Extreme economic underdevelopment, predatory governance and rent seeking by state agencies especially the military, has led to lawlessness and disorder to the extent that the center cannot guarantee minimum security to the civilians. Criminal networks more often than not take advantage of insecurity and have established regional criminal networks engaged in cattle trade, money laundering, fraud, selling of counter felt goods. The net effect has been chronic insecurity at community level. Militia activities together with army defections have complicated security sector rendering it unstable and unpredictable [Enough project, 2015:6-11; Magnus, 2017; Irin, 2014:7]. A cattle raiding for commercial purposes are fairly common among communities and creates inter-ethnic raids and cross border raids in Kenya and Ethiopia. The practice is evident among all pastoral communities and proliferation of small arms and light weapons reinforces the practice. Cross border criminal networks, drugs, poaching, fraud, stolen oil are a major and emerging threats to national and international security

The legacy of war, economic free fall and underdevelopment, Rampant or ubiquitous corruption, inflation and serious economic crises have weakened the state and taken away the little legitimacy that might have been left and the ability of the state to offer social services. Nicolaissen [2015:36-51] observes that trade among frontline states has declined drastically since 2013 as compared to the period 2005-2008 when regional trade boomed. The war has seen significant fall due to shortage of hard currency and inflation.
Zenebe [2015] argues that internal factors are the biggest challenge to survival. Furthermore, he notes that the post-colonial state lacks the capacity to respond to basic needs of the public such as economic prosperity, security and welfare. As most of the states are multiethnic, national integration, than exclusion and marginalization are equally necessary through the reconfiguration and democratization of the state to reduce conflicts. There are known weak political, economic and social dislocations of the African state attributed to state failures and non-performance of key state institutions. This in many cases calls for state dismemberment and different manner of state political engineering. The internal factors that Zabene makes reference to be attributed to five key factors- colonial legacy, internal political decay and foreign economic dependency. Of course there are trickle-down effects on every variable with devastating outcome and generally accepted as important units of analyzing conflicts in Africa [Wimmer, 2013:6-9; Matelits, 2014:7-8; Dagne, 2011:5-7].

The Republic of South Sudan faces a devastating security challenges associated with the war, unresolved border demarcations, nomads and citizens' movements and arms conflicts with Sudan. Internally, poor infrastructure and general underdevelopment, misuse of natural resources and inter communal conflicts in the Greater upper Nile region are part and parcel of the security breakdown. Arms conflicts have occasionally erupted depending on the local and regional power matrixes with the result that many people are killed and many more internally displaced [Dagne, 2011; ICG, 2015; Obasanjo, 2015; Knopf, 2016]. The number of internally displaced persons in South Sudan is estimated in millions. Security implications of such a big number of displaced persons is that, most of them are dependent on the international community for humanitarian assistance and protection, others flee the country by crossing national borders for save heavens and livelihood as refugees. Such persons could not get involved in any productive work as a result of their personal insecurity. For example, the war between Sudan People's Liberation Army/In Opposition, SPLA IO led by Dr. Riek Machar on one hand, and the Sudan People's Liberation Army, SPLA, National arms forces on the other, in Juba on 7-8 July 2016, highlights the plight of the internally displaced persons during and after the war and speaks volumes in security gaps and lapses (Collier and Bannon, 2015; Collier, 2013). With the highest numbers of internally displaced persons and refugees outside the country posing a security risk similar to Rwanda before 1994 genocide (AU report, 2015)

Olusagen Obasanjo [2014:4-13; Knopf, 2016:5-11] argues that there are political, social and economic triggers of war in Africa. Politically, he observes that state building processes such as power struggle by the elites, unconstitutional change of government, and poor governance in general are political triggers of conflict in 
Africa. Economically, unequal distribution of resources, corruption and struggle for control of ownership of natural resources not only trigger but also can sustain conflicts especially when the resources are on high demand in the international markets. Studies by Pierre Englebert on both the Democratic Republic of Congo and Congo Brazzaville in early 2000 established the link between economic drivers of war and politics [Englebert, 2003:52-61]. Similar observations can be made of South Sudan and natural resources as noted earlier. Socially, the post independent state, South Sudan included, lacks capacity for diversity management. This is further compounded by high social inequalities and marginalization along ethnic and religious lines. Other factors considered, as possible causes of conflicts in Africa are alienation and consequent disillusionment of the youth; foreign interference in political transitions. Herbst and Mills (2015:11-16) classify them into three categories as peace and security, democracy and governance, and economic growth and development. Paul Collier [2015:16-21] however thinks that there are only two emerging security threats in Africa namely Radical Islam and natural resources discoveries. What is important and clear in the case of South Sudan is the extent to which natural resources and oil fuel conflict and regionalized insecurity. In fact the Dinka and Nuer has no conflict of their own, so to speak, but only lured into the ongoing war as a result of power struggle among the elites in the SPLM leadership.

The political, social and economic factors are intertwined and collectively define the nature of the emerging security threats in East Africa. The identity politics and ethnic manipulation in South Sudan has witnessed inter-communal conflicts across the country. The military and political elites have exploited such social cleavages to increase their power and bargain for their upward political mobility as they struggle for political power and influence.

The political factors especially the manner in which the state is configured and can manage ethnic diversity and address the social challenges associated with state and nation building is key determinant in laying a solid foundation that can hold South Sudan together. The lessons from the evolution of the Sudan People's Liberation Movement from 1983-2005 suggests that the SPLA was a fighting organization that placed emphasis on the military than political outcomes of the war [De Waal, 2014:11-16]. Thus, it did not have a theory of national liberation of post liberation reconstruction agenda. The task of nation building is primarily a political one and not entirely military. South Sudan is a geographical territory without glue that can hold the now evolving nation state together. The political art of statecraft in South Sudan require fundamental restructuring of the state, economy and society with aim of creating social and political glue that can hold the country together. The task of doing that falls on the SPLM to undertake the necessary yet painful reforms and transformation capable of sustaining both state and nation building. The political transformation agenda is the primary and most fundamental security tool, which others gravitate to.

Since December 2013, civil war in South Sudan erupted afresh due to power struggle within the SPLM sparking violence in Juba and other part of South Sudan along ethnic lines. United Nations, USA, European Union and African Union diplomacy forced a ceasefire and subsequent return of Machar to Juba in April 2016. Fresh war between Kiir and Machar forces in Juba erupted again in July 2016 leading to defacto collapse of the peace agreement and the disintegration of the transitional government of National Unity. Just like the persistent conflicts since 1991, killings and civil war in South Sudan is politically motivated and according to African Union Commission of inquiry report in 2013, crimes against humanity were committed "pursuant to or furtherance of state policy"(AU report, 2015:13). The assumption here is that central to emerging security challenge is a political challenge that pits two principals in South Sudan war, President Salva Kiir and former vice president Riek Machar. A political problem calls for a political solution that has evaded South Sudan for decades. What is clear is that the political strife and rifts between the two principals has created sustained civil war to date. The war has caused unchecked violence, humanitarian catastrophe, social displacement and economic collapse.

While addressing high level security conference in Ethiopia in 2016, Kofi Annan, a former United Nations Secretary and top diplomat, in his speech noted that rebel groups operate within ungoverned spaces or impoverished parts of weak states in Africa where security agencies or militias abuse civilians. He noted three variables central to peace and security in Africa-inclusive development, respect for rule of law and human rights. His emphasis on the political dimensions of the conflicts was illuminating. He noted that the biggest political challenge was about acquisition and use of power and creating jobs for the youth. South Sudan has all the hall marks that Kofi Annan was describing and caused insecurity both within and without (Annan, 2016:4-9).

The external factors respond to the dynamics of the state and how it is perceived as either strong or a weak state. The west has always rallied the world to occupy ungoverned spaces that are regarded as avenues for terrorists. In South Sudan, the external pull factors are attributed to the resources and ungoverned spaces that attract transnational non-state actors and state actors alike. This has created political tensions and security challenges in South Sudan and among the front line neighbors. The obsession with stability and control of natural resources in ungoverned spaces has created a plethora of security challenges that cuts across the region and beyond. In other cases, it has compromised peoples quest for democracy and democratization processes in Africa. The status quo is 
preferred conditionally and this betrays people's hopes and aspirations leading to civil wars and state failure as the case in South Sudan.

South Sudan is viewed as a buffer zone against Sudan regime in Khartoum and its neighbors in the South. Commercial interests and security factors converge to make the security factor a regional one with both gains and losses socialized within the region but with unequal measure. Thus from the introduction, we note the importance of the Copenhagen school of security as adequate in explaining the emerging security threats in South Sudan and their impact on her neighbors.

The domestic attributes of the war have regional and international dimensions are noted earlier. The regional implications of security vary depending on the national interests of the front line states and the availability of natural resources at strategic locations. Geo-political considerations and interests of the global players together with other pull and push factors shape the emerging security dimensions in South Sudan. Regional rivalries and power struggles are some of the emerging security threats as countries influence the war in South Sudan in favor of their national interests. The role of Uganda, Kenya, Ethiopia and Sudan in determining the political transition in South Sudan should be viewed against the background of the emerging security threats. The following section focuses on how the emerging threats could be addressed to ensure sustainable peace and security in East Africa.

\section{Addressing Emerging Security Threats in South Sudan}

One of the biggest challenges facing the post-colonial state in Africa is creating a viable, strong and sustainable state in Africa and this is the basic challenge facing south Sudan at the moment. The fact that the challenges are not unique to South Sudan rather are part of Africa's state evolutionary challenges suggest a Copenhagen security school approach towards finding a lasting solution as earlier noted in the introduction. Firstly, security challenges in South Sudan are intertwined with those of its neighbors hence a regional security solution is appropriate. Secondly, the security challenges emanating from within South Sudan can be addressed through the involvement of the international development agencies such as the East African community, African Union and the United Nations, among other international actors. Furthermore, the ongoing war in South Sudan is as a result of the Sudan People's Liberation Movements inability to resolve the social and national question associated with the colonial legacy and emerging neoliberal globalization [Magnus, 2017:6]. The end of the cold war brought about other dimension to the liberation of South Sudan that were overlooked within the movement or assumed. Thus, the manner in which the struggle was conducted and the political settlement reached introduced new challenges of both state and nation building that require international support and accelerated intervention.

The role of Uganda in resolving the ongoing war warrants reexamination. Uganda has historically influenced the manner in which SPLA/M has evolved and conducted the armed struggle in South Sudan together with post-independence reconstruction phase. The international community needs to appreciate that the reforms sought from within cannot be successfully undertaken without similar reforms in Uganda [Mamdani, 2016:6-21]. That is to say that the political destiny of South Sudan is linked to that of National Resistance Movement in Uganda. The same observations could be made of the role front line states played in determining the political direction of the front line states in Southern Africa. In particular the recognition that liberation movements do not hand over power to non-liberation agencies or political after years of waging armed struggle. The solution to South Sudan political crises laid within the SPLM hence the need to initiate reforms from within.

The most serious challenge outside direct security parameters is economic. Other than building a petroleum economy, the South Sudan government has to build a national economy from the scratch together with supportive institutional infrastructure. Such challenges require a comprehensive master plan that goes beyond occasional resources mobilization. The challenge is to diversify the economy and create a self-sustaining structure especially in the non-oil sectors. The government needs to invest more in agriculture, infrastructure and health through public sector in the short and medium term to socialize public gains and win the hearts and minds of the people as one way of reaping the dividends of peace.

The government, with the support of the international community needs to support the government of South Sudan to create and sustain public institutions of accountability to undertake fundamental economic reforms that would make the state more efficient and effective in the delivery of public goods and services. Such measures include retrenchments and training, currency stabilization, security sector reforms and constitutional reforms to create a new social contract.

The World Bank [2011:1] survey on Africa concluded that about $40 \%$ joined rebel movements due to unemployment thus making youth unemployment a very significant security variable in Africa. South Sudan has higher levels of unemployed youths who liberally join rebel movements or militias and have been instrumental in armed conflicts and human rights violations across South Sudan. The inclusion and training of youth in vocational skills such as masonry, construction, mechanics, information and communication technology, agriculture and animal husbandry among other vocational skills would be important in disengaging them from the war economy. In other words, more resources need to deploy towards 
youth empowerment and development.

African economies as Kofi Anan [2016:2-6] observed had recorded substantial growth over the last 15 years while extreme poverty has fallen by $40 \%$ since 1990 . However, such growth was not driven by productive sectors of the economy but narrowly driven by construction, manufacturing, finance and telecoms. This excludes crucial sectors such as agriculture. Furthermore, the role of the state in the economy and in directing development is largely overlooked in favor of the weak private sector. In South Sudan, the role of the state in the economy needs to be strengthened and diversified.

Democracy and good governance is a prerequisite for development and political stability in South Sudan. As we have noted, security is essentially a contested and value laden concept dependent on who uses the term and for what purpose. The causes of insecurity and emerging threats are caused and attributed to the nature of the state and its evolution. A neopatrimonial South Sudan has excluded most of its citizens in politics and economy hence resentment and war. An all-inclusive state that satisfactorily answers the social and national question would significantly inspire people's hopes and aspirations for a better South Sudan [Magnus, 2017:5-16]. A political solution that takes into consideration contending and competing interests within and without would be durable.

The emerging security threats are intertwined with those of the front line states hence important to equally tackle transnational threats prevalent within the region. Joint security measures related to security of the people need to be undertaken to secure people's confidence in the state security agencies now perceived as partisan or corrupt and in service of regions strong men. Security agencies are seen as personalized and repressive towards realizing political goals as opposed to national good across the region. The multiple tasks require the intervention of the west, the United Nations, European Union and African Union and regional agencies to be sustainable.

\section{Conclusions}

The essay noted the changed security challenges have their genesis in the manner, which the SPLM/A was formed and undertook, armed national liberation since 1983. Furthermore, we have noted that SPLM failed to secure legitimacy in pre and post independent period due to its failure to resolve the social and national question leading to persistent conflicts, wars, underdevelopment and ultimately state collapse. The external factors have not resolved the emerging security challenges but further factionalized the domestic environment. The cumulative effect has been securitization of all aspects of society and cycle of insecurity in South Sudan. The paper observes the centrality of political and the cause and solution to the serious and multiple emerging security threats in South
Sudan.

\section{REFERENCES}

[1] African Union Commission of inquiry report in December 2015, Addis Ababa.

[2] Bereketeab, R (2014) post liberation state building in South Sudan: potentials and challenges in Journal of Foreign Affairs vol. 1 no 1 pages 25-60.

[3] Buzan, B. (2007). People, states and fear: an agenda for international security studies.

[4] Barry, B. \& others (1998). Security: a new framework for analysis, Lynne Rienner.

[5] Collier, P (2013), Equity in extractives, Africa progress report.

[6] Collier, P and Bannon, I (2015) natural resources and violent conflicts: options and actions, World Bank.

[7] De Waal, A (2014) When Kleptocracy becomes insolvent: Brute causes of the civil war in South Sudan in African Affairs, Volume 113, issue 452

[8] De Waal, A (2014) a political market place: Analyzing political entrepreneurs and political bargaining with a business lens, World Peace Foundation, October 17

[9] Dagne, T. (2011) the republic of South Sudan: opportunities and challenges for Africa's newest country, Congressional research service, July 1, 2011.

[10] Herbst, J. \& Greg, M. (2015). Emerging risks and opportunities in Sub Saharan Africa in PRISM, Vol 5 no 2.

[11] Irin(2014) Regional interests in South Sudan, March 19.

[12] Fanny, N; Tove H. S.; \& Oystein, R. (2015) South Sudan Uganda relations, ACCORD paper.

[13] International Crises Group, (2015). Sudan and South Sudan merging conflicts report no 223, Africa, July 27, 2015.

[14] Mamdani, M (2016) who is to blame in South Sudan, Boston Review

[15] Metelits, C. (2014). Security threats in Africa: Critical perspectives, Rowman and Littlefield Publishers.

[16] Magnus, T. \& Nils, P. G. (2017). Resources, the Environment and conflict in Eds Myriam Dunn Cavelty \& Thierry Balzacq, Routledge Hand book of security studies, second edition, Routledge, New York.

[17] Muriithi, J W (2014) effects of South Sudan instability on Kenyas economy and human security: a case study of Nairobi and Turkana counties, Master of Arts thesis, IDHIS, University of Nairobi.

[18] Wimmer, A. (2013). States of war: how the nation state made modern conflict, Foreign Affairs, November.

[19] Enough Project (2015). Weapons of mass corruption: How corruption in South Sudan military undermines the world's 
country, a report.

[20] Kofi, Anan (2016). Speech delivered at Tana High level forum on security in Africa, 16-17 $7^{\text {th }}$ April 2016 in Bahir Dar, Ethiopia.

[21] Knopf, K. A. (2016). Ending South Sudan civil war, Special report no 77, Council on Foreign Relations, Center for Preventive Action, USA.

[22] Kenya Bureau of Standards, Economic survey, 2013.

[23] Obala, LM (2012) South Sudan and Kenya: the relationships,
Aljazeera center for studies.

[24] Obasanjo, O. (2015). States of peace and security in Africa in PRISM, Vol 5 no 2.

[25] International Crisis Group (2015). Sudan and South Sudan: Merging conflict in Africa, report no 223, 2015.

[26] World Bank (2011) Survey on Africa

[27] Zenebe, A. M. (2014). The quest of the African state for viability, democracy and development for national integration in Africa, a seminar paper. 